\title{
Harga Pokok Produksi dalam Penetapan Harga Jual Ikan Asin di Pengolah Ikan Desa Asemdoyong Kecamatan Taman Kabupaten Pemalang
}

\author{
[Cost of Production in Stipulation of Fish Selling Price in Fish Processing \\ Village Asemdoyong District Park Regency of Pemalang] \\ Sobariah \\ Jurusan Penyuluhan Perikanan - Sekolah Tinggi Perikanan \\ Jalan Cikaret Nomor 2 Bogor, Jawa Barat
}

Diterima: 8 Juni 2016; disetujui: 15 Juli 2016

\begin{abstract}
Abstrak
Penelitian ini bertujuan untuk mengetahui bagaimana penetapan harga pokok produksi dalam menentukan harga Jual ikan asin dengan mengidentifikasi factor factor yang mempengaruhi harga pokok produksi. Diantaranya adalah biaya-biaya ytang dikeluarkan dalam memproduksi ikan asin kacangan, yang dilakukan oleh pengolah ikan asin kacangan.. Penelitian dilakukan di pengolahan ikan asin kacangan desa Asemdoyong Kecamatan Taman.Kabupaten Pemalang JawaTengah. Dengan melibatkan 10 orang pengolah yang dipilih secara acak dan beberapa pedagang sebagai responden yang diwawancara. Kegiatan pengolahan didesa asemdoyong yang dilakukan pengolah sangat sederhana ,ke,nmasanpun sangat sederhana sehingga penelitian ini dapat menentukan biaya-biaya yang digunakan untuk mengolah ikan sehingga harga pokok dapat dihitung sehingga dapat menntukan harga jual. Analisis data dilakukan secara deskriptif kualitatif. Hasil penelitian menunjukkan: bahwa dari identifikasi biaya biaya dan perhitungan harga jual perkilogram dengan kesepakatan yang dibuat antar pengolah ikan biaya- biaya yang digunakan selama proses produksi serta nilai rupiah yang diperoleh asin yaitu harga jual adalah Rp.9000,- dengan keuntungan pengolah setiap kali produksi memperoleh sebesar $=$ Rp 4.871.429 - atau setiap kilogram mendapat keuntungan sebesar Rp. 1.550,.Walaupun kegiatan tersebut cukup sederhana baik dalam pengolahannya maupun pengemasannya, akan tetapi sudah dapat menghasilkan kelebihan dari harga pokok produksi senbesar Rp.1550,- $/ \mathrm{kg}$, ( Rp.9.000 - 7.450 ), pengolah masih tetap eksis menjalankan usahanya, dengan demikian perhitungan harga pokok cukup berperan untuk menetapkan harga jual ikan asin disetiap kegiatan produksinya,
\end{abstract}

Kata kunci: harga jual, harga pokok

\begin{abstract}
This study aims to determine how the determination of the cost of production in determining the selling price of salted fish by identifying factor factors that affect the cost of production. Among them are the costs incurred in producing salted fish, which is done by the processing of salted fish. The research was done in the processing of salted fish of Asemdoyong village Kecamatan Taman.Kabupaten Pemalang Jawa Tengah. Involving 10 randomly selected and multiple processors raders as respondents interviewed. The processing of the village asemdoyong done by the rocessor is very simple, to the very simple, so the research can determine the costs used to rocess the fish so that the cost of goods can be calculated so that it can determine the selling price. Data analysis was done descriptively qualitative. The result of the research shows that from Dentification of cost cost and calculation of selling price of perkilogram with agreement which have been made between fish processing cost which used during production process and value roduction earned $=\operatorname{Rp} 4,871,429$ - or each kilogram profit of Rp. 1.550, -of rupiah obtained salt that is selling price is Rp.9000, - with processing profit every time. Thus, although the activity is quite simple both in processing and packaging, but already can produce the excess of the cost of production senbesar Rp.1550, - / kg, (Rp.9.000 - 7,450), the processor still exist to run its business, and thus Calculation of the cost of production is enough role to determine the selling price of salted fish in every production activity.
\end{abstract}

Keywords: calculation, cost factor, criteria

$\triangle$ Penulis korespondensi

Alamat surel : sobariahana@yahoo.com

Jurnal Penyuluhan Perikanan dan Kelautan 


\section{PENDAHULUAN}

Pada dasarnya kegiatan pengusaha pengolahan ikan dimanapun, selalu berusaha menghasilkan barang yang berkualitas tinggi namun harganya relatif rendah. Agar hal tersebut dapat tercapai maka pengusaha pengolah komoditi ikan menggunakan biaya relatif efektif. Biaya produksi akan sangat diperlukan untuk menentukan harga pokok produksi suatu produk. Biaya yang dikeluarkan untuk menghasilkan produk harus jelas, sehingga penentuan harga pokok produksinya akan tepat. Ketidak tepatan dalam perhitungan harga pokok produksi akan menyesatkan manajemen dalam membuat keputusan. Harga pokok produksi yang merupakan kumpulan dari berbagai biaya-biaya yang dikeluarkan untuk mengolah bahan baku menjadi barang jadi. Dalam hal ini pengolah ikan asin dalam menentukan harga pokok unit produksinya, adalah menghitung semua biaya yang akan terjadi diperlakukan untuk biaya unit produksi sehingga terdapat berbagai unsur biaya non produksi yang dimasukkan dalam elemen harga pokok produksi. Sehingga mengakibatkan ketidaktepatan dalam suatu perhitungan harga pokoknya dan juga akan berpengaruh terhadap penetapan harga jual dan laba usaha. Menurut Abdul Halim, (2009), harga dapat ditentukan atau dihitung: Harga didasarkan pada biaya total ditambah laba yang diinginkan (cost plus pricing method).

Untuk itu maka dapat diharapkan pengusaha komoditi ikan asin ini mampu menentukan harga pokok yang tepat sehingga dapat bersaing dengan pengusaha lain yang sejenis. Untuk itu penelitian ditujukan pada kajian penetapan harga pokok produksi pengolahan ikan asin kacangan di areal Desa Asem Doyong Kecamatan Taman Kabupaten Pemalang.

Permasalahan yang dikaji dalam penelitian ini adalah: (1) Metode apakah yang digunakan dalam menentukan harga pokok produksi pengolahan komoditi ikan asin kacangan di Kecamatan Taman Kab. Pemalang; (2) Komponen biaya apa saja yang digunakan dalam menentukan harga pokok produksi Pengolahan komoditi ikan asin kacangan; dan (3) Bagaimanakah cara perhitungan harga pokok produksi ikan asin kacangan.

Penelitian ini bertujuan: (1) untuk mengetahui metode yang digunakan dalam menentukan harga pokok unit produksi pengolahan ikan asin kacangan; (2) untuk mengetahui komponen semua biaya yang digunakan dalam menentukan harga pokok produksi pengolahan ikan asin Kacangan; dan (3) untuk mengetahui cara perhitungan harga pokok produksi Pengolahan Ikan asin Kacangan. 
Kerangka pemikiran penelitian ini adalah untuk mengetahui: Harga Pokok produksi (X) adalah variabel bebas yang merupakan skor yang diperoleh dari pengukuran dengan menggunakan angket sebagai variabel bebas harga Pokok mempunyai dua dimensi, (1) dimensi pertama yaitu jenis Harga pokok Produksi dan dapat diukur dengan perhitungan biaya yang dikeluarkan yaitu seberapa besar peluangnya biaya biaya tersebut menjadi dasar perhitungan harga jual, biaya produksi yaitu bagaimana perputaran atau pencatatan biaya biaya bahan baku, tenaga kerja langsung dan biaya overhead pabrik (bop), dan (2) sedangkan dimensi kedua adalah efektivitas dan dapat diukur dengan mengetahui seberapa manfaat harga pokok produksi dapat mengukur harga jual (y) vaiabel terikat apakah biaya biaya tersebut sudah sesuai dengan atuan-aturan yang ada. Biaya produksi adalah merupakan biaya-biaya yang terjadi untuk mengolah bahan baku menjadi produk jadi yang siap jual.

Dari uraian diatas maka dapat dikemukakan hipotesis sebagai berikut: Diduga terdapat pengaruh biaya biaya bahan baku, biaya langsung dan biaya overhead terhadap perhitungan harga jual barang yang diproduksi

\section{BAHAN DAN METODA}

Penelitian dilakukan pada suatu unit pengolahan ikan asin di desa Asem Doyong Kecamatan Taman Kabupaten Pemalang, selama tiga bulan dari bulan Juli sampai Oktober 2015.

Populasi adalah orang yang dengan kegiatan pengolah ikan asin yang ada didesa Asem Doyong Kecamatan Taman Kabupaten Pemalang. populasinya dari warga pengolah ikan asin yang tergabung dalam kelompok pengolah ikan asin sebanyak 21 kelompok ada di desa Asem doyong Kecamatan Taman, dengan perkiraan suatu karakteristis dari kegiatan ekonomi yaitu usaha pengolahan ikan Asin. Sebanyak tujuh kelompok dari 21 kelompok pengolah ikan asin. populasi dengan teknik sampling yaitu simple random sampling.

Pengumpulan semua data dengan menggunakan sumber data primer yaitu pengolah ikan asin di desa asem doyong dan sumber sekunder dengan melihat data dari laporan kelompok pengolah ikan asin adapun caranya yaitu dengan cara interview/wawancara, kuesioner (angket), observasi (pengamatan) dan gabungan dari ketiganya.

Teknik analisa semua data yaitu mengkelompokan data berdasar variabel dan jenis responden, mentabulasi data 
berdasrkan responden, menyajikan data tiap variabel yang diteliti dan melakukan perhitungan untuk menguji hipotesa. Analisa data yang dilakukan dengan analisa deskriptif statistic .

\section{HASIL DAN PEMBAHASAN}

Pengolah ikan asin di desa asemdoyong juga merupakan kelompok pengolah yang telah memiliki modal dari kegiatan per-kelompok dimana mereka tergabung dalam beberapa kelompok, dalam 21 kelompok terdiri dari 5-7 orang anggota, pengolah ikan menghasilkan ikan asin dengan berbagai jenis ikan dari hasi hasil tangkapan nelayan diseputar desa tersebut, adapun hasil tangkapannya berupa ikan-ikan yang tertera pada Tabel 1.

Dari Tabel 1 diatas bahwa jenis ikan yang dihasilkan berbagai jenis ikan, lebih dominan pada ikan jenis kacangan. Untuk itu dalam penelitian ini yang dipilih ikan jenis kacangan, karena dalam hasil wawancara lebih banyak pada jenis ikan kacangan. Menurut Usry dan White (2000) bahan baku disebut bahan langsung (direct materials) adalah semua bahan yang membentuk bagian integral barang jadi dan dapat dimasukkan langsung dalam kalkulasi biaya produk. Abdurrahim (2007) serta Basu \& Irawan (2002) menyatakan bahwa dalam biaya adalah pengeluaran-pengeluaran baiaya atau nilai pengorbanan untuk memperoleh barang atau jasa yang berguna untuk masa yang akan datang, atau mempunyai manfaat melebihi satu periode akuntansi; selain itu Dwinta dkk (2013) menyatakan bahwa harga sering dijadikan indikator kualitas bagi pelanggan: harga yang lebih murah. Harga adalah Jumlah Uang (ditambah beberapa barang) yang dibutuhkan untuk memperoleh beberapa kombinasi sebuah produk dan layanan yang menyertainya" (Aries, 2012; Agustin, 2011).

Tabel 1. Komoditas hasil tangkapan, dan kebutuhan bahan baku dalam produksi ikan asin

\begin{tabular}{cccccccccc}
\hline $\begin{array}{c}\text { Komoditas } \\
\text { Per 3 hari }\end{array}$ & $\begin{array}{c}\text { Jumlah } \\
\text { Bahan Baku } \\
\text { Kg / Bakul }\end{array}$ & $\begin{array}{c}\text { Harga / } \\
\text { kg }\end{array}$ & Produksi & $\begin{array}{c}\text { Harga } \\
\text { jual }\end{array}$ & TK & Garam & Listrik & Air & Angkut \\
\hline Kacangan & 3.000 & 7.000 & 2.000 & 12.000 & & & & & \\
Kacangan & 3.000 & 6.000 & 2.000 & 12.000 & 4.500 .000 & 150.000 & 100.000 & 50.000 & 1.500 .000 \\
Kacangan & 2.000 & 6.000 & 2.000 & 12.000 & 4.000 .000 & 150.000 & 100.000 & 50.000 & 1.500 .000 \\
Kacangan & 3.000 & 6.000 & 2.000 & 12.000 & 4.500 .000 & 150.000 & 100.000 & 50.000 & 1.500 .000 \\
Kacangan & 2.000 & 6.000 & 1.600 & 12.000 & 4.000 .000 & 150.000 & 100.000 & 50.000 & 1.500 .000 \\
Kacangan & 4.500 & 3.000 & 3.000 & 12.000 & 6.500 .000 & 150.000 & 100.000 & 50.000 & $2000 . .000$ \\
Kacangan & 4.500 & 3.000 & 3.000 & 12.000 & 4.500 .000 & 150.000 & 100.000 & 50.000 & 2000.000 \\
\hline
\end{tabular}

Sumber : data diolah tahun 2015 
Bahan yang nilainya relatif kecil tidak dikelompokan menjadi bahan penolong. Dalam penetapan harga jual ada beberapa strategi penetapan harga seperti berikut: Penetapan harga yang berpedoman pada biaya. Cara yang ditempuh yaitu dengan menambah prosentase laba dan biaya.

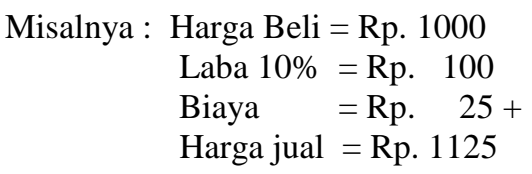

Harga jual $=$ Harga pokok + biaya + laba

Harga pokok produksi ikan asin. Untuk menggambarkan harga pokok produksi pengolahan ikan asin Kacangan di desa Asemdoyong pada Kecamatan Taman areal Kabupaten Pemalang yaitu dengan mendata dan menghitung biaya-biaya yang dikeluarkan oleh pengolah komoditi ikan asin Kacangan (Pracoyo, 2006). Menurut Hongren et al. (2002) biaya didalam pengertian umum adalah sebagai sumber daya yang dikorbankan untuk mencapai suatu sasaran/tujuan tertentu. Lebih lanjut Slat (2013) menyatakan ada penggolongan biaya seperti upah langsung adalah semua upah yang secara langsung digunakan, dapat secara mudah ditelusuri, dan merupakan biaya upah yang utama untuk memproduksi suatu produk (Edward \& Wells, 1979). Tenaga kerja merupakan usaha fisik atau mental yang dikelu: 103 karyawan untuk mengolah produk, yaitu ibu Sarmi seperti tertcantum dalam Tabel 2. Selain biaya-biaya diatas untuk mendukung kegiatan produksi ikan asin di perrlukan alat-peralatan, adapun biaya peralatan yang digunakan digambarkan pada Tabel 3. Selanjutnya untuk menjalankan pengolahan ikan kacangan menjadi ikan asin kacangan, juga mengeluarkan biaya lainnya dalam proses produksi seperti tergambar pada Tabel 4.

Biaya sewa kendaraan adalah $\mathrm{Rp}$ 500.000/ satukali angkut, dalam produksi per bulan 3-4 kali angkut, maka dalam satu tahun, biaya sewa kendaraan adalah 48 dikalikan dengan jumlah biaya yang dikeluarkan sebesar Rp 500.000, maka dalam satu tahun adalah $\mathrm{Rp}$ 24.000.000, untuk biaya sewa.

Gambaran tentang unsur-unsur biaya produksi di atas dapat dihitung Harga Pokok Produksi (HPP) total per hari seperti digambarkan pada Tabel 5. 
Tabel 2. Biaya Bahan Baku/Bahan Langsung per produksi

\begin{tabular}{clccr}
\hline No & Bahan Baku & Harga(Rp)/kg & Volume & \multicolumn{1}{c}{ Total } \\
\hline 1. & Ikan Kacangan basah & 7000 & 3 ton & 21.000 .000 \\
2. & Garam & 300 & $3 \mathrm{kw}$ & 900.000 \\
3. & Air bersih & 500 & 200 galon & 100.000 \\
4. & Kayu bakar & $2000 /$ ikt & 2 truk & 300.000 \\
5. & Minyak tanah & 12000 & $10 \mathrm{ltr}$ & 120.000 \\
\hline & \multicolumn{2}{c}{ Jumlah } & & 22.420 .000 \\
\hline
\end{tabular}

Sumber : data di olah

Tabel 3. Biaya Peralatan yang digunakan dalam proses produksi ikan asin

\begin{tabular}{|c|c|c|c|c|c|c|}
\hline No & Peralatan & Banyak & $\begin{array}{c}\text { Harga } \\
\text { (Rp) }\end{array}$ & $\begin{array}{l}\text { Total } \\
\text { (Rp) }\end{array}$ & $\begin{array}{l}\text { Masa } \\
\text { pakai*) }^{*}\end{array}$ & $\begin{array}{l}\text { per Bulan } \\
(\mathbf{R p})\end{array}$ \\
\hline 1 & Wajan besar & 3 & 170.000 & 510.000 & 5 th & 8500 \\
\hline 2 & Tungku api & 2 & 500.000 & 1.000 .000 & 10.th & 8.333 \\
\hline 3 & Bak besar & 2 & 30.000 & 60.000 & 5 th & 1.000 \\
\hline 4 & Panci air & 21 & 125.000 & 2.150 .000 & 10 th & 17.917 \\
\hline 5 & Jerigen & 5 & 25.000 & 125.000 & 5 th & 2.083 \\
\hline 6 & Baskom besar & 3 & 35.000 & 105.000 & 5 th & 1.750 \\
\hline 7 & Sutil besar & 2 & 37.500 & 75.000 & 3 th & 2.083 \\
\hline 8 & Pisau & 7 & 15.000 & 90.000 & 2 th & 3.750 \\
\hline 9 & Talenan & 3 & 11.000 & 33.000 & 2 th & 1.375 \\
\hline 10 & Keranjang bambu & 10 & 25.000 & 250.000 & 2 th & 10.417 \\
\hline 11 & Rak penjemur & 50 & 50.000 & 2.500 .000 & 3 th & 69.444 \\
\hline 12 & Lap & 10 & 10.000 & 100.000 & 1 th & 8.333 \\
\hline 13 & Drum air bersih & 3 & 75.000 & 225.000 & 3 th & 6250 \\
\hline 14 & Gayung & 2 & 10.000 & 20000 & 2 th & 556 \\
\hline 15 & Kerangjang pelastik & 3 & 45.000 & 135.000 & 2 th & 5625 \\
\hline \multirow[t]{2}{*}{16} & Kerangjang pelastik & 3 & 45.000 & 135.000 & 2 th & 5625 \\
\hline & Total & & & & & $\begin{array}{l}151.350 / 30 \\
=5.353\end{array}$ \\
\hline
\end{tabular}

Sumber: data pengolah ikan asin yang diolah

Keterangan: *) per tahun dan habis pakai

**) metode yang digunakan adalah metode rata-rata

Tabel 4. Biaya lain-lain yang dikeluarkan dalam proses produksi ikan asin

\begin{tabular}{clll}
\hline No & Biaya Lainnya & Per bulan $($ Rp) & Per hari $($ Rp) \\
\hline 1 & Biaya sewa mobil $\left.^{* * *}\right)$ & 2.000 .000 & $2000.000 / 30 \mathrm{hr}=67.000$ \\
2 & Biaya listrik $_{3}$ & 90.000 & 3000 \\
4 & Biaya Air & 60.000 & 2.000 \\
\hline & BBM & 180.000 & 60.000 \\
\hline
\end{tabular}

Sumber: data diolah 
Tabel 5. Harga Pokok Produksi (HPP) Total

\begin{tabular}{rlr}
\hline No & Biaya Produksi & Per hari (Rp) \\
\hline 1 & Biaya bahan-bahan & \\
2 & Biaya Overhead & 60.000 \\
& - BBM & 67.000 \\
& - Biaya sewa kendaraan & 3.000 \\
- Biaya listrik & 2000 \\
- Biaya Air & 5.353 \\
- Biaya Penyusutan & $873.903,0$ \\
\hline
\end{tabular}

Sumber: data diolah

Menurut kajian Manurung (2012)

perhitungan Harga Pokok Produksi (HPP)

dengan Metode Full Costing masih mendapatkan keuntungan sebesar Rp $905.903+122.000=1.027 .903$ Ini berarti rata-rata keuntungan yang dinikmati per harinya adalah Rp $343 / \mathrm{kg}$. Uraian diatas, sejalan dengan yang dimukakan oleh Apadbuista et al. (2014).

\section{Ketepatan dalam Menetapkan Harga Jual Ikan Asin Kacangan}

Untuk memberikan gambaran bahwa kecermatan perhitungan harga pokok produksi mempengaruhi ketepatan dalam menetapkan harga jual pengolahan ikan asin kacangan, kembali pada contoh perhitungan HPP pengolahan ikan asin kacangan di atas.

Tabel 6. Perhitungan HPP ikan asin kacangan

\begin{tabular}{llrlr}
\hline Bahan Baku & $\begin{array}{c}\text { Biaya Tidak } \\
\text { Tetap }\end{array}$ & \multicolumn{1}{c}{ Harga } & \multicolumn{1}{c}{ Biaya Tetap } & \multicolumn{1}{c}{ Harga } \\
\hline Ikan Kacangan & Ikan Kacangan & 22.420 .000 & Panci air & 280.000 \\
Garam & Garam & 900.000 & Wajan besar & 600.000 \\
Air bersih & Air bersih & 100.000 & Jerigen & 80.000 \\
Kayu bakar & Kayu bakar & 300.000 & Sutil besar & 50.000 \\
Minyak tanah & Minyak tanah & 120.000 & Baskom besar & 175.000 \\
& Upah musiman & $60.000 \times 3=180.000$ & Keranjang bambu & 50.000 \\
& 3 org & 16.000 & Pisau & 50.000 \\
& Pelastik & 3.000 & Talenan & 15000 \\
& Kardus & 7.500 & Rak penjemur & 150.000 \\
& Lakban & 500.000 & Bangku besar & 250.000 \\
& Sewa & & Drum air bersih & 200.000 \\
& mobil/kapal & & Gayung & 30.000 \\
& & Kerangjang pelastik & 35.000 \\
& & Lap & 10.000 \\
& & Gaji bag menyiangi 3 org & $25.000 / / \mathrm{hr}$ \\
& & Gaji bag pengolah 3 org & $50.000 / \mathrm{hr}$ \\
& & Gaji bag penjemur 1 org & $20.000 / \mathrm{hr}$ \\
& & Gaji bag pemasar 2 org & $200.000 / 1 \mathrm{x}$ \\
& & & pemasar \\
\hline
\end{tabular}

Sumber : data diolah 
Disini akan dicermati perhitungan masingmasing unsur biaya produksi ikan asin. Menurut Londong et al. (2014) Activitybased costing system (ABC) pada dasarnya merupakan metode penentuan harga pokok produk (product costing) yang ditujukan untuk menyajikan informasi harga pokok produk secara cermat (accurate) bagi kepentingan manajemen, Untuk perhitungan HPP ikan asin kacangan dapat dilihat dalam Tabel 6.

\section{Perhitungan Biaya Overhead Pabrik (BOP)}

Quality adalah merupakan kepuasan pelanggan (Hansen \& Mowen, 2006). Dengan kata lain kualitas merupakan karakteristik suatu produk, dapat berupa barang atau jasa, yang kemampuannya adalah memenuhi kebutuhan yang telah disesuaikan dengan tujuannya atau segala sesuatu yang memuaskan konsumen. Kembali memperhatikan perhitungan pengolahan ikan asin ada yang masih harus dicermati seperti belum dibebankannya biaya dus, palstik pembungkus, lakban kalau saja diperkirakan masing-masing per hari Rp 296.829,- maka total tambahannya adalah Rp 525.500 Ini berarti BOP sesungguhnya pengolahan ikan asin adalah Rp $296.829+$ Rp .525.500,- = Rp 822.329.

\section{Harga Pokok Produksi (HPP) Ikan Asin Kacangan yang Sesungguhnya}

Mencermati perhitungan diatas dapatlah dihitung sesungguhnya Harga Pokok Produksi (HPP) ikan asin kacangan secara total adalah Biaya bahan baku $=\mathrm{Rp}$ 24..909.329,-Biaya tenaga kerja langsung $=\operatorname{Rp} 295.000 .,-$ Biaya overhead pabrik $=$ Rp 612.829.(+) Total biaya ikan asin kacangan $=R p$. 25.817.158. Harga pokok produksi per $\mathrm{kg}$ dapat dihitung yaitu $\mathrm{Rp}$ $25.817 .158: 3.143 \mathrm{~kg}=\operatorname{Rp} 8.214 / \mathrm{kg}$ jadi harga pokok preoduksi Rp. 8214/kg. Dengan demikian harga jual per $\mathrm{kg} \mathrm{Rp}$ 8.214,- berarti keuntungan per $\mathrm{kg}=\mathrm{Rp}$ 10.000 - Rp. $8.214=$ Rp 1.786,-/kg Ratarata keuntungan per $\mathrm{kg}=\mathrm{Rp} .1 .786 / \mathrm{kg}$. Dengan demikian angka keuntungan sesngguhnya bagi pemilik pengolahan ikan asin adalah Rp 5.358.000,- per satu kali produksi

\section{Penetapan Harga Jual Per Kilogram}

Dalam penetapan harga jual perkilogram ikan asin sesuai yang disampaikan oleh pakar ekonomi bahwa harga adalah jumlah uang (ditambah beberapa produk kalau mungkin) yang dibutuhkan untuk mendapatkan sejumlah kombinasi dari produk dan pelayanannya. 
Menurut Dwinta dkk (2013) harga merupakan jumlah uang yang diperlukan sebagai penukar kombinasi produk dan jasa, dengan demikian maka suatu harga haruslah dihubungkan dengan bermacammacam barang dan/ atau pelayanan, yang akhirnya akan sama dengan sesuatu produk dan jasa. Sedangkan harga jual (seles price) adalah nilai berupa uang, termasuk semua biaya yang diminta atau seharusnya diminta oleh penjual karena penyerahan barang tidak termasuk Pajak Pertambahan Nilai. Menurut Setiyaningsih \& Dian (2004), actual costing An actual cost system use actual costs for direct materials, direct (manufacturing) labor, and (manufacturing) overhead. These actual costs are then used to determined the unit cost Dalam penetapan harga jual ada beberapa strategi penetapan harga seperti berikut : Penetapan harga yang berpedoman pada biaya. Biaya yang dikeluarkan dengan kegiatan perhari selama 30 hari. Cara yang ditempuh yaitu dengan menambah prosentase laba dan biaya yaitu: Harga beli bahan baku = 22.420.000/30 = Rp. 746.667. Laba $20 \%$ $=\mathrm{Rp} 149.333$; Harga jual = Rp. $=$ $24.909 .329 / 3000=$ Rp. $8.303 / \mathrm{kg}$ dibulatkan menjadi - Rp 8.300,-+ $20 \%$ keuntungan $=1660$; maka harga jual per$\mathrm{kg}=\mathrm{Rp} 9.960$ dibulatkan keatas menjadi Rp.10.000 per-kg
Dengan disepakati bahan baku yang digunakan serta bahan tambahan tersebut, maka kesepakatan harga jual perkilo adalah dari harga pokok produksi 108 ibah dengan laba estimasi sebesar $20 \%$, untuk itu disepakati harga jual per $\mathrm{kg}$ adalah Rp10.000,- seperti tulisan yang disampaikan Martusa el al. (2009) bahwa Perusahaan dapat menetapkan harga jual dengan tepat apabila perusahaan dapat menghitung harga pokok produk dengan tepat sehingga produk tidak overcosted (dibebani biaya lebih dari yang seharusnya) dan juga tidak undercosted (dibebani biaya kurang dari yang seharusnya). Menurut Hariadi (2002), definisi aktivitas adalah: "Kumpulan kegiatan yang dilakukan dalam organisasi yang bermanfaat bagi manajer untuk tujuan perencanaan, dan pengendalian, serta pengambilan keputusan"

\section{Manfaat Harga Pokok Produksi}

Menurut Mulyadi (2005) informasi harga pokok produksi bermanfaat bagi manajemen dalam: Menentukan harga jual produk. Perusahaan yang berproduksi massa memproses produknya untuk memenuhi persediaan di gudang. Dengan demikian biaya produksi dihitung untuk jangka waktu tertentu untuk menghasilkan informasi biaya produksi per satuan produk (Hilton, 2005; Moehar, 2002) 
Menurut Setiyaningsih \& Dian (2004), actual costing An actual cost system use actual costs for direct materials, direct (manufacturing) labor, and (manufacturing) overhead. These actual costs are then used to determined the unit cost Dalam penetapan harga jual ada beberapa strategi penetapan harga seperti berikut :

Penetapan harga yang berpedoman pada biaya. Biaya yang dikeluarkan dengan kegiatan perhari selama 30 hari. Cara yang ditempuh yaitu dengan menambah prosentase laba dan biaya yaitu: Harga beli bahan baku $=22.420 .000 / 30=$ Rp. 746.667. Laba $20 \%$ = Rp149.333; Harga jual = Rp. $=24.909 .329 / 3000=$ Rp. $\quad 8.303 / \mathrm{kg}$ dibulatkan menjadi - Rp 8.300,-+ $20 \%$ keuntungan $=1660$; maka harga jual per$\mathrm{kg}=\mathrm{Rp} 9.960$ dibulatkan keatas menjadi Rp.10.000 per-kg

Dengan disepakati bahan baku yang digunakan serta bahan tambahan tersebut, maka kesepakatan harga jual perkilo adalah dari harga pokok produksi ditambah dengan laba estimasi sebesar $20 \%$, untuk itu disepakati harga jual per $\mathrm{kg}$ adalah Rp10.000,- seperti tulisan yang disampaikan Martusa el al. (2009) bahwa Perusahaan dapat menetapkan harga jual dengan tepat apabila perusahaan dapat menghitung harga pokok produk dengan tepat sehingga produk tidak overcosted (dibebani biaya lebih dari yang seharusnya) dan juga tidak undercosted (dibebani biaya kurang dari yang seharusnya). Menurut Hariadi (2002), definisi aktivitas adalah: "Kumpulan kegiatan yang dilakukan dalam organisasi yang bermanfaat bagi manajer untuk tujuan perencanaan, dan pengendalian, serta pengambilan keputusan"

\section{Manfaat Harga Pokok Produksi}

Menurut Mulyadi (2005) informasi harga pokok produksi bermanfaat bagi manajemen dalam: Menentukan harga jual produk. Perusahaan yang berproduksi massa memproses produknya untuk memenuhi persediaan di gudang. Dengan demikian biaya produksi dihitung untuk jangka waktu tertentu untuk menghasilkan informasi biaya produksi per satuan produk (Hilton, 2005; Moehar, 2002)

\section{SIMPULAN}

Dari hasil kegiatan penelitian tentang harga pokok ikan asin dan dari perhitungan yang diperoleh dari pengolahan data, maka penetapan harga pokok dapat dilihat dari biaya = biaya yang digunakan dalam proses produksi dan dari perhitungan harga jual per kilogram dengan kesepakatan yang telah dibuat antar pengolah ikan asin dimana harga yang disepakati untuk harga 
barang dan/ atau pelayanan, yang akhirnya jual adalah Rp 10.000,- dengan keuntungan pengolah setiap produksi sebesar $=\mathrm{Rp}$ 5.358.000 per sekali produksi. Dari kegiatan pengolahan ikan asin ini setiap kilogramnya mendapat keuntungan sebesar Rp 1.768,- dimana dari hasil kegiatan pengolahan dapat menutupi biaya-biaya yang dikeluarkan selama proses produksi dengan lama waktu prosesnya cukup sederhana, serta cara pengemasanpun sangat sederhana pula namun pemasarannya sudah cukup jauh hingga sampai keluar pulau jawa yatiu Palembang, Bengkulu, Jakarta, Bogor dan Sumatera Barat.

Dengan demikian walaupun kegiatan tersebut terlihat cukup sederhana dalam pengolahannya dan dapat menghasilkan kelebihan harga dari harga pokok produksi senbesar Rp.1768- per-kg, pengolah masih tetap eksis menjalankan usahanya, dan dengan demikian perhitungan harga pokok produksi ini cukup berperan untuk menetapkan harga jual ikan asin disetiap kegiatan produksinya. Produksi ikan asin masih dalam tahap berjalan karena karna 110 I kegiatan pengolahan sangat sederhana begitupun dalam hal pengemasan masiih sangat sederhana. Juga proses higienis akan pengolahan masih harus terus diberikan penyuluhan tentang pentingnya higienisasi.
Saran yang dapat dikemukakan dalam hal ini adalah: egiatan produksi pengolahan ikan asin agar dapat lebih berkembang lagi terutama dalam hal proses pengemasannya, juga proses higienisasi terutama dalam penjemuran ikan tersebut masih perlu peningkatan demi mendapatkan hasil olahan ikan asin yang berkualitas.

\section{DAFTAR PUSTAKA}

Abdurahim. 2007. Ekonomika pertanian. Penebar Swadaya. Jakarta

Abdul Halim, (2009), Akuntansi biaya, Yogyakarta, BPFE

Agustin. 2011. Metode harga pokok pesanan-proses.

http://agustin.staff.gunadarma.ac.id/ Downloads/file/11395/metode+harga +pokok+pesanan_proses.doc/diunduh tanggal 8 Juli 2011/Pukul 13.01

Apadbuista, E Rosher, dan HR Yuliantoro. 2014. "Penerapan metode full costing untuk perhitungan harga jual produk pada industri kecil (studi kasus home industry citra snack Pekanbaru)." Jurnal Akuntansi Keuangan dan Bisnis Vol 20 (27)

Aries H., 2012. Teori Ekonomi Produksi. Brilian Internasional. Surabaya

Basu Swastha, DH Irawan. 2002. "Azasazas marketing. akademi keuangan dan bisnis (akb).

Dwinta DL, WD Sayekti, A Nugrah. 2013. Analisis harga pokok produksi dan strategi pengembangan industri pengolahan ikan teri nasi kering di pulau pasaran Kecamatan Teluk Betung Barat kota Bandar Lampung) JIIA, Vol 1 (2) 
Edward W and A Wells. 1979. The Economif of Agricultural Production. Alfred Publishing Co. United States of America

Manurung EM. 2012. Akuntansi dasar untuk pemula. Erlangga. Jakarta

Hariadi B. 2002, "Akuntansi manajemen suatu sudut pandang." Yogyakarta: BPFE Yogyakarta

Hansen DR, dan MM Mowen. 2006. 7th Edition. Management accounting. Thomson: Southwestern Publishing, Co.

Hilton RW. 2005. International edition. managerial accounting. New York: McGraw Hill, Inc.

Hongren H, dan Secokusumo. 2002. Akuntansi di Indonesia. Salemba Empat. Jakarta

Moehar D. 2002. Pengantar ekonomi pertanian. Bumi Aksara. Jakarta

Mulyadi. 2005. Analisis ekonomi usaha nelayan dan pengolahan hasil. PT Raja Grafindo Estrada. Jakarta

Martusa R, SR Darma, dan V Carolina. 2010. Peranan metode activity based costing dalam menentukan cost of goods manufactured. Jurnal Ilmiah Akuntansi, Vol. 1 (2): 39-60. Bulan Mei-Agustus

Pracoyo TK. 2006. Aspek dasar ekonomi mikro. PT Gramedia Widiasarana Indonesia. Jakarta

Slat AH. 2013 "Analisis harga pokok produk dengan metode full costing dan penentuan harga jual." Jurnal
Riset Ekonomi, Manajemen, Bisnis dan Akuntansi 1.3

Usry ML, and Marion White. 2000. "Multicultural awareness in small businesses." Business Forum. Vol. 25. (1/2). California State University, Los Angeles, School of Business and Economics, 2000

Longdong E, dan VZ. Tirayoh. 2014. "Analisis penggunaan informasi akuntansi diferensial dalam pengambilan keputusan manajemen menerima atau menolak pesanan khusus pada modern taylor." jurnal riset ekonomi, manajemen, bisnis dan akuntansi Vol 2 (3)

Setiyaningsih E, dan D Nuswantoro. 2004. "Analisis penerapan metode full costing dalam perhitungan harga pokok produksi untuk penetapan harga jual (studi kasus pada pabrik tahu lestari). Hansen, Don R. Akuntansi manajemen: Buku 1. Vol. 1. Penerbit Salemba, 